\title{
Soybean cropping systems on sandy soil of the Caiuá Sandstone formation in Northwestern Paraná, Brasil
}

\section{Sistemas de produção de soja em solo arenoso da formação Arenito Caiuá no Noroeste do Paraná}

\author{
Ivan Bordin ${ }^{1 *}$; Nilson dos Santos Silva ${ }^{2}$; Tiago Roque Benetoli da Silva ${ }^{3}$; Josiane \\ Bürkner dos Santos ${ }^{1}$; Luciano Grillo Gil ${ }^{1}$; Lutécia Beatriz dos Santos Canalli ${ }^{1}$; \\ Ronaldo Hissayuki Hojo하 ${ }^{1}$ Rafael Fuentes Llanillo ${ }^{1}$
}

\section{Highlights:}

First-crop corn and winter congo grass are the largest contributors to soybean dry matter yields.

Soybeans can reach the largest grain yields when sown after white oats harvesting.

After three crop years, soil chemical properties were not changed by the cropping systems.

\begin{abstract}
Extensive cattle ranching had been the most common farming practice in northwestern Paraná State (Brazil), where soils originate from the Caiuá Sandstone. But this reality is changing with the growing cultivation of grain crops, especially soybeans. This study aimed to evaluate different soybean cropping systems in terms of yield components, plant dry matter, and soil chemical properties. The soil is classified as a dystrophic sandy Red Argisol, which derived from the Caiuá Sandstone, in northwestern Paraná State (Brazil). The experiment was carried out in the city of Umuarama (PR), Brazil, under a no-till system for three years. Treatments consisted of the following crop rotation systems: T1: congo grass/soybeans, congo grass/soybeans, congo grass/soybeans; T2: black oats + rye/soybeans, black oats + radish/grain sorghum, black oats + rye/soybeans; T3: triticale/corn, grain sorghum/soybeans, triticale/ soybeans; T4: crambe/grain sorghum, canola/corn, safflower/soybeans; T5: lupine/corn + congo grass, beans/corn, buckwheat/black oats/congo grass. The experiment was arranged in a randomized block design, with four replications and $300-\mathrm{m}^{2}$ plots. The data were subjected to analysis of variance, and means were compared by the Tukey's test at 5\% significance. The highest grain yield was obtained when soybeans were sown after white oats harvesting. Plant dry matter increased in the system with lupine/corn + congo grass, beans/corn, buckwheat/white oats/soybeans. However, none of the systems had an effect on soil chemical properties during the three crop years.
\end{abstract}

Key words: Plant dry matter. Glycine max. Soil carbon.

\section{Resumo}

O sistema de produção agropecuário mais comum na região noroeste do Paraná em solos originários do Arenito Caiuá é a pecuária bovina extensiva. Porém, esta realidade está mudando com o crescente

\footnotetext{
1 Pesquisadores, Instituto de Desenvolvimento Rural do Paraná, IAPAR, EMATER, IDR-PARANÁ, Londrina, PR, Brasil. E-mail: ivanbordin@iapar.br; santosjb@iapar.br; lggil@iapar.br; lutecia@iapar.br; ronaldo@iapar.br; rfuentes@iapar.br

2 M.Sc., em Ciências Agrárias, Universidade Estadual de Maringá, UEM, Umuarama, PR, Brasil. E-mail: nilsonengenheiro.agro@, gmail.com

3 Prof. Dr., Departamento de Ciências Agronômicas, UEM, Umuarama, PR, Brasil. E-mail: trbsilva@uem.br

"Author for correspondence.
}

Received: Nov. 27, 2019 - Approved: Apr. 28, 2020 
cultivo de grãos, principalmente da cultura da soja. Componentes de produção da soja, matéria seca vegetal e atributos químicos do solo em sistemas de produção de soja foram avaliados em ARGISSOLO VERMELHO Distrófico arênico originado do Arenito Caiuá no Noroeste do Paraná. O experimento foi conduzido em Umuarama-PR, em sistema plantio direto durante três anos. Os tratamentos (T1: braquiária/soja, braquiária/soja, braquiária/soja; T2: aveia preta + centeio/soja, aveia preta + nabo/ sorgo granífero, aveia preta + centeio/soja; T3: triticale/milho, sorgo granífero/soja, triticale/soja; T4: crambe/sorgo granífero, canola/milho, cártamo/soja; T5: tremoço/milho + braquiária, feijão/milho, trigo mourisco/aveia preta/soja) foram instalados em delineamento experimental de blocos ao acaso com quatro repetições, com $300 \mathrm{~m}^{2}$ por parcela. Os dados foram submetidos à análise de variância e as médias comparadas pelo teste de Tukey a 5\% de significância. A soja tem maior produtividade de grãos após a cultura da aveia branca. O sistema de produção com tremoço/milho+braquiária, feijão/milho, trigo mourisco/aveia branca/soja, aumenta o aporte de matéria seca vegetal. Os atributos químicos do solo não são alterados pelos sistemas de produção avaliados, após três anos de cultivo.

Palavras-chave: Matéria seca vegetal. Glycine max. Carbono do solo.

\section{Introduction}

Soybeans have played an increasing role in the world's agriculture and stand out as one of the most relevant products in the Brazilian economy. Soybean area in Brazil is expected to increase by 9.3 million hectares in the next 10 years, reaching 20.22.2 million hectares in 2027. Such expansion is believed to occur mainly on pasture lands (Ministério da Agricultura, Pecuária e Abastecimento [MAPA], 2017). In Paraná state, this expansion has consolidated in the last crop years, occupying about 5.465 million hectares in the $2019 / 20$ harvest, with production close to 20.4 million tons (Secretaria da Agricultura e do Abastecimento - Departamento de Economia Rural [SEAB/DERAL], 2020).

Most soils in northwestern Paraná are sandy and originated from the Caiuá Sandstone, which is dominated by planted pastures, extensive cattle ranching, and poorly modernized farms (Llanillo, Grossi, Santos, Munhos, \& Guimarães, 2006). In this region, soybeans have been an alternative for restoration of degraded pastures. However, local edaphoclimatic conditions may hinder soybean yields, due to several negative factors (high temperature, low chemical fertility, and low soil water retention) during soybean vegetative cycle (Barbosa et al., 2013; Fidalski et al., 2010).

No-till (NT) is a suitable system for soil use and management in northwestern Paraná. Crop rotation has been recommended to increase yield stability in soybeans, using plant species with high dry matter yields and abundant and aggressive root systems (Franchini, Debiasi, Sacoman, Nepomuceno, \& Farias, 2009). For Franchini et al. (2016), soybeans have shown higher yields in sandy soils when grown after different species of brachiaria, mainly Urochloa ruziziensis, rather than other tropical forage species. Such finding was assigned to the fastest soybean root growth, increasing tolerance to dry spells.

Among the advantages of NT, changes in soil chemical properties stand out (Campos, Leite, Maciel, Iwata, \& Nóbrega, 2011). In this sense, crop rotation must consider several plant families since distinct species contribute differently to amount and quality of remaining residue from the previous harvest, nutrient absorption efficiency, and exploration of different soil depths by the root system (H. P. Santos, Fontaneli, Spera and Tomm, 2009).

The low fertility of sandy soils from the Caiuá Sandstone has been associated with low total organic carbon (TOC) contents. These contents may decrease due to intensive annual cropping or increase due to forage cropping (Fidalski et al., 2010; Marun, 1996). For Rosset et al. (2016), crop succession systems contribute more to increases in labile (in uppermost depths) than to recalcitrant $\mathrm{C}$ fractions. Therefore, soil organic matter (MOS) 
fractions, such as labile organic carbon (LOC) and mineral-associated organic carbon (MOC), must be balanced to understand the dynamics of soil chemical fertility, as cover plant residues strongly influence MOS within a few years, corroborating the findings of Tivet et al. (2013), while MOC has been associated with longer-term management (Sá et al., 2014 ).

This study aimed to evaluate crop yield components, plant dry matter, and soil chemical properties in soybean cropping systems carried out for three years in a soil originated from the Caiuá Sandstone, in northwestern Paraná State, Brazil.

\section{Material and Methods}

The experiment was carried out at the IAPAR's experimental station, which is in the city of
Umuarama (Paraná State), Brazil (23\%44' South, $53^{\circ} 17^{\prime}$ West, and 480-m altitude). Previously, the area had been grown under a no-till system for five years, among which four grown with black oats in winter and soybeans in summer and one with radish in winter and corn in summer. According to Köppen's classification, the climate is humid subtropical (Cfa), with means of $22.1{ }^{\circ} \mathrm{C}$ and 1,600 $\mathrm{mm}$ for annual temperature and rainfall, respectively (Instituto Agronômico do Paraná [IAPAR], 2020). Figure 1 shows the water balance in the 2016/2017 crop year. The soil is classified as dystrophic sandy Red Argisol (H. G. Santos et al., 2018). Grain-size distribution analyzed by the pipette method (Gee \& Bauder, 1986) and showed the following: $110 \mathrm{~g}$ clay, $30 \mathrm{~g}$ silt, and $860 \mathrm{~g}$ sand per $\mathrm{kg}$ soil at depth layers of $0.0-0.10$ and $0.10-0.20 \mathrm{~m}$.

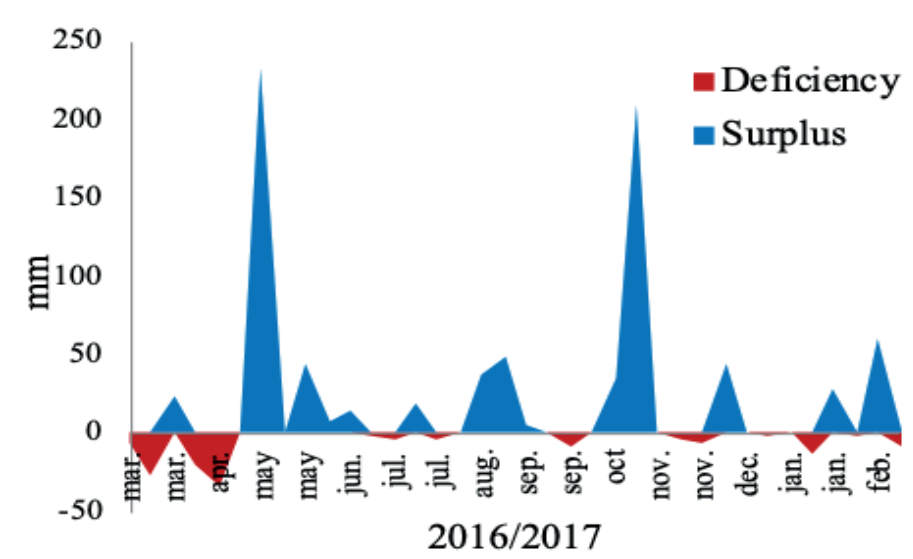

Figure 1. Ten-day water balance in the agricultural year 2016/2017 $(\mathrm{cad}=60$ mm). Umuarama, Paraná State, Brazil.

Treatments (Table 1) were carried out under notill (NT) system and conducted over three crop years (from 2014 to 2017). They consisted of the following: $\mathrm{T} 1$ - soybean cropping in all summers on brachiaria straw grown in all winters; T2 - commercial crops in summer (soybeans and grain sorghum) and straw in winter (black oats + rye and black oats + radish); T3 - several species for grain production in winter and summer; T4 - various summer and winter oil crops for commercial purposes; T5 - commercial crops in summer (corn and soybeans) and in winter (beans and buckwheat) plus soil cover crops (lupine and white oats).

Crop management was performed as a function of the recommendations for each species. At the end of the third year (October 5, 2016), soybeans were sown (Brasmax Ícone IPRO) in all treatments at a 
between row spacing of $0.45 \mathrm{~m}(222,000$ plants per hectare), using a seeder-fertilizer combine (model GA 2715- P), applying $280 \mathrm{~kg} \mathrm{ha}^{-1} 00-20-20$ NPK formulation $\left(\mathrm{N}-\mathrm{P}_{2} \mathrm{O}_{5}-\mathrm{K}_{2} \mathrm{O}\right)$. Weeds were controlled by applying $1.44 \mathrm{~kg}$ ai ha ${ }^{-1}$ Glyphosate $+0.02 \mathrm{~kg}$ ai $\mathrm{ha}^{-1}$ Ethyl-carfentrazon for pre-planting desiccation and $1.08 \mathrm{~kg}$ ai ha-1 Glyphosate in post-emergence. Pest control was done by three sprays of $35 \mathrm{~g}$ ai ha-1 Thiamethoxam +26 g ai ha ${ }^{-1}$ Lambda-Cyhalothrin. Leaf diseases were controlled by two sprays of $60 \mathrm{~g}$ ai ha ${ }^{-1}$ Trifloxystrobin $+70 \mathrm{~g}_{\text {ai ha }}{ }^{-1}$ Prothioconazole.

\section{Table 1}

\section{Treatments of soybean production systems. Umuarama, Paraná State, Brazil}

\begin{tabular}{|c|c|c|c|c|c|c|}
\hline \multirow{2}{*}{ Treatments } & \multicolumn{2}{|c|}{$2014 / 2015$} & \multicolumn{2}{|c|}{$2015 / 2016$} & \multicolumn{2}{|c|}{$2016 / 2017$} \\
\hline & winter & summer & winter & summer & winter & summer \\
\hline 1 & congo grass & soybean & congo grass & soybean & congo grass & soybean \\
\hline 2 & $\begin{array}{c}\text { black oats }+ \\
\text { rye }\end{array}$ & soybean & $\begin{array}{l}\text { black oats }+ \\
\text { radish }\end{array}$ & sorghum & $\begin{array}{c}\text { black oats }+ \\
\text { rye }\end{array}$ & soybean \\
\hline 3 & triticale & corn & sorghum & soybean & triticale & soybean \\
\hline 4 & crambe & sorghum & canola & corn & safflower & soybean \\
\hline 5 & lupine & $\begin{array}{c}\text { corn }+ \text { congo } \\
\text { grass }\end{array}$ & bean & corn & $\begin{array}{c}\text { buckwheat/ } \\
\text { white oats }\end{array}$ & soybean \\
\hline
\end{tabular}

The soybean yield components evaluated were the following: plant height, 1,000-grain weight, and numbers of grains per pod, pods per plant, and grains per plant. They were determined using two samples per 1-m plot. Soybean yield was estimated by harvesting three 10 -meter $\left(13.5 \mathrm{~m}^{2}\right)$ rows, using a Wintersteiger combine harvester (classic model), with grain moisture corrected to $13 \%$.

Shoot dry matter of all crops were determined in four samples of $0.25 \mathrm{~m}^{2}$ per plot, collected at physiological maturation of each species. The samples were dried in a forced ventilation oven at $60^{\circ} \mathrm{C}$ for 72 hours.

Soil chemical analyses were carried out in composite samples (four subsamples), collected from each plot in March 2017 (after soybean harvest). These samples were taken with the aid of an auger from the depth layers of 0.00-0.05, 0.050.10 , and $0.10-0.20 \mathrm{~m}$. The soil chemical properties estimated were as follows: $\mathrm{pH}$ in $0.01-\mathrm{M} \mathrm{CaCl}_{2}$, calcium $(\mathrm{Ca})$, magnesium $(\mathrm{Mg})$, aluminum $(\mathrm{Al})$ by 1-M KCl method, potassium (K), phosphorus (P) by
Mehlich-1 method, and potential acidity $(\mathrm{H}+\mathrm{Al})$ by SMP method, calculating the sum of bases (SB), cation exchange capacity (CEC), and base saturation (V \%) (Pavan, Block, Zempulski, \& Miyazawa, 1992). Soil organic matter was fractionated using the procedure proposed by Cambardella and Elliott (1992) and modified by J. B. Santos (2010), for each depth layer, to determine fractions of labile organic carbon (LOC) above $53 \mu \mathrm{m}$ particulate and mineral-associated organic carbon (MOC) below $53 \mu \mathrm{m}$ particulate. Total organic carbon (TOC), LOC, and MOC were assessed by wet oxidation by the Walkley and Black method, while soil bulk density (Sbd) by the volumetric ring method at the same depth layers (Empresa Brasileira de Pesquisa Agropecuária [EMBRAPA], 2017). For TOC, LOC, and MOC stocks at each depth, Equation 1 was used:

$$
\mathrm{Cst}=(\mathrm{C} \times \mathrm{Sbd} \times \mathrm{LT}) / 10(\text { Equation } 1)
$$

Wherein:

Cst $=$ stock of organic carbon at a given depth $\left(\mathrm{Mg} \mathrm{ha}^{-1}\right)$; 
$\mathrm{C}=$ total organic carbon content or content in particle size fractions $\left(\mathrm{g} \mathrm{dm}^{-3}\right)$;

$\mathrm{Sbd}=$ soil bulk density in each depth layer $(\mathrm{Mg}$ $\left.\mathrm{m}^{-3}\right)$;

$\mathrm{LT}=$ depth layer thickness $(\mathrm{m})$.

The experimental design was a randomized block with five treatments and four replications, with $300-\mathrm{m}^{2}$ plots $(20 \times 15 \mathrm{~m})$. The data underwent analysis of variance (ANOVA) and means compared by the Tukey's test at 5\% significance, using the SAS software (Institute Statistical Analysis System [SAS], 2009).

\section{Results and Discussion}

Treatments had no significant effect on soybean plant height and number of grains per pod (Table 2). Such parameters are associated with genetic factors, which means that each cultivar responds variously to each treatment, plant spacing, plant density, and climatic conditions (Silva et al., 2014). Linzmeyer, Guimarães, Santos and Bencke (2008) reported that soybean height increases and stem diameter decreases are directly related to plant population growth. In our study, this lack of response can be explained because only one soybean cultivar was evaluated, under standardized spacing and being sown at the same time, i.e., under the same climatic conditions.

Table 2

Soybean production components in third year of production systems (2016/2017). Umuarama, Paraná State, Brazil

\begin{tabular}{ccccccc}
\hline \multirow{2}{*}{ Treatments } & Height & Grain/pod & 1.000 grains mass & Pod/plant & Grains/plant & Yield \\
\cline { 2 - 7 } & $\mathrm{cm}$ & $\mathrm{n}^{\mathrm{o}}$ & $\mathrm{g}$ & $\mathrm{n}^{\mathrm{o}}$ & $\mathrm{n}^{\mathrm{o}}$ & $\mathrm{kg} \mathrm{ha}$ \\
\hline 1 & $87.0 \mathrm{a}$ & $2.13 \mathrm{a}$ & $148 \mathrm{a}$ & $62.0 \mathrm{ab}$ & $129 \mathrm{ab}$ & $3,007 \mathrm{c} \mathrm{c}^{-1}$ \\
2 & $89.0 \mathrm{a}$ & $2.19 \mathrm{a}$ & $149 \mathrm{a}$ & $54.2 \mathrm{~b}$ & $115 \mathrm{~b}$ & $3,285 \mathrm{bc}$ \\
3 & $86.0 \mathrm{a}$ & $2.17 \mathrm{a}$ & $156 \mathrm{a}$ & $63.2 \mathrm{ab}$ & $136 \mathrm{ab}$ & $3,406 \mathrm{ab}$ \\
4 & $89.7 \mathrm{a}$ & $1.99 \mathrm{a}$ & $156 \mathrm{a}$ & $66.0 \mathrm{a}$ & $130 \mathrm{ab}$ & $3,436 \mathrm{ab}$ \\
5 & $86.5 \mathrm{a}$ & $2.20 \mathrm{a}$ & $161 \mathrm{a}$ & $68.7 \mathrm{a}$ & $149 \mathrm{a}$ & $3,780 \mathrm{a}$ \\
\hline C.V. $(\%)$ & 9.1 & 14.1 & 8.4 & 10.6 & 12.2 & 7.2 \\
\hline Test F & n.s. & n.s & n.s. & $*$ & $*$ & $*$ \\
\hline
\end{tabular}

$*$ and n.s. $=$ significant at $5 \%$ probability and not significant. Averages followed by same letter in the column. do not differ by Tukey test. C.V. = coefficient of variation.

Moreover, the treatments did not significantly influence 1000-grain weight (Table 2). Carvalho, Athayde, Soratto, Alves and Arf (2004) obtained a similar result and highlighted that among all crop yield components, 1000-grain weight has the least effect due to changes in the growth environment. These authors also suggested that such an outcome could be due to the main biological goal of plants, that is, the perpetuation of the species.
In terms of pod number per plant, treatments 5 and 4 were superior to 2 but similar to 1 and 3 . While for grains per plant, treatment 5 was superior to 2 but similar to the others (Table 2). Grain yield was also higher in treatment 5 if compared to 1 and 2, but similar to 3 and 4 (Table 2). The highest grain yield in treatment 5 is because the parameters that best express grain yield in soybeans are the number of pods per plant and grains per plant (Perini, Fonseca, Destro, \& Prete, 2012; Barbosa et al., 2013). 
Treatment 5 had total dry matter contents higher than those in 1 and 4, which were higher than those in 2 and 3 (Table 3). The lower contents of dry matter in treatments 2 and 3 are related to low dry matter yields in intercropping between black oats + rye and black oats + radish in winter for treatment 2 , and triticale and grain sorghum in treatment 3 . The low dry matter yields of crambe and safflower in treatment 4 were offset by corn growing in summer, while in treatment 1 the low dry matter yield of soybeans in summer was compensated by the high dry matter yield of brachiaria in winter. In treatment 5 , the poor performance of beans was also offset by corn in summer, as well as lupine in winter (Tables 1 and 3). According to Alvarenga Cabezas, Cruz and Santana (2001), $6 \mathrm{Mg} \mathrm{ha}^{-1}$ dry matter is enough to provide good soil coverage. When considering that six crops were evaluated over the three years of the experiment, an amount of $36 \mathrm{Mg} \mathrm{ha}^{-1}$ total dry matter would be suitable to maintain a good soil coverage in a crop rotation system. Sá et al. (2015) observed that to balance $\mathrm{C}$ contents in soils of the Cerrado region in Mato Grosso State, the minimum amount of plant dry matter to be added into a crop rotation system varies from 11.7 to $13.3 \mathrm{Mg} \mathrm{ha}^{-1}$ per year. In this sense, we concluded that only treatment 5 had the potential to accumulate $\mathrm{C}$ in the soil, although there are balanced conditions in 1 and 4, but a decrease in 2 and 3 (Tables 2 and 3). However, the previous five years and the three years of the experiment add up to eight years under NT, which characterizes a transition phase between nutrient mineralization and accumulation of plant dry matter and MOS (Sá et al., 2019).

Table 3

Crops dry matter used in soybean production systems. Umuarama, Paraná State, Brazil

\begin{tabular}{|c|c|c|c|c|c|c|c|}
\hline \multirow{3}{*}{ Treatments } & \multicolumn{7}{|c|}{ Dry matter $\left(\mathrm{Mg} \mathrm{ha}^{-1}\right)$} \\
\hline & \multicolumn{2}{|c|}{$2014 / 2015$} & \multicolumn{2}{|c|}{$2015 / 2016$} & \multicolumn{2}{|c|}{$2016 / 2017$} & \multirow{2}{*}{ Total } \\
\hline & winter & summer & winter & summer & winter & Summer & \\
\hline 1 & 6.18 & 3.22 & 8.52 & 4.87 & 10.95 & 4.06 & $37.79 b^{*}$ \\
\hline 2 & 5.22 & 3.58 & 5.12 & 5.57 & 5.34 & 4.12 & $28.95 \mathrm{c}$ \\
\hline 3 & 3.93 & 7.28 & 4.55 & 4.11 & 2.99 & 4.23 & $27.09 \mathrm{c}$ \\
\hline 4 & 3.04 & 7.80 & 5.69 & 10.40 & 3.95 & 4.24 & $35.13 \mathrm{~b}$ \\
\hline 5 & 11.54 & $7.53^{* *}$ & 3.19 & 9.85 & $5.97 * *$ & 4.45 & $42.52 \mathrm{a}$ \\
\hline C.V. $(\%)$ & & & & & & & 7.2 \\
\hline
\end{tabular}

** = add two crops. * Averages followed by same letter in the column. do not differ by Tukey test.

C.V. $=$ coefficient of variation.

Soybeans in treatment 5 had a higher yield than in 1 (brachiaria/soybeans) (Table 2), which is widely used in the region (Franchini et al., 2016). This was due to the cropping of buckwheat and white oats before soybeans in treatment 5 (Table 1). According to Wendler and Simonetti (2016), buckwheat is an alternative for crop rotation with soybeans, as it has no negative effect on soybean germination and increase number of standard seedlings. Debiasi,
Leiven, Trein, Conte and Kaminura (2010) reported that, after harvesting oats, soybean yield increased in a drier crop year. For Franchini, Costa, Debiasi and Torres (2011), white oats preceding soybeans is the best choice to increase grain yield.

Another factor that may have increased grain production in treatment 5 was the fact that the white oats harvest is close to soybean sowing. This may have increased soil cover during soybean cycle and 
increased water storage and availability, which are limiting factors for soybeans in sandy soils with low water retention, such as those derived from the Caiuá Sandstone (Fidalski et al., 2010). Also, soybean production potential might have increased, even after negative water balance in November, December, and January (Figure 1). According to Barbosa et al. (2013), an increasing number of pods is related to higher water availability for soybeans between R1 and R4 stages, which reduces pod abortion.
Crop rotation systems had no significant effect on soil chemical properties (Table 4). As stated by Campos et al. (2011), it cannot be seen within the first years of no-till cropping, but only after six to nine years. Sá et al. (2019) demonstrated that, after 11 years of no-till in the region of Campos Gerais in Paraná, straw started to accumulate on the soil surface, increasing $\mathrm{C}$ stock and hence improving soil chemical properties.

Table 4

Chemical attributes of soil at three depths in soybean production systems. Umuarama, Paraná State, Brazil

\begin{tabular}{|c|c|c|c|c|c|c|c|c|c|c|c|c|c|}
\hline & $\mathrm{P}$ & $\mathrm{pH}$ & $\mathrm{Al}$ & $\mathrm{H}+\mathrm{Al}$ & $\mathrm{Ca}$ & $\mathrm{Mg}$ & $\mathrm{K}$ & $\mathrm{S}$ & $\mathrm{T}$ & $\mathrm{V}$ & TOC & LOC & MOC \\
\hline \multicolumn{2}{|c|}{$\mathrm{mg} \mathrm{dm} \mathrm{m}^{-3}$} & & \multicolumn{7}{|c|}{-------------cmol $\mathrm{dm}^{-3}$------------ } & $\%$ & \multicolumn{3}{|c|}{----------Mg ha'-1--------- } \\
\hline \multicolumn{14}{|c|}{$0.0-0.05 \mathrm{~m}$} \\
\hline Average & 34.7 & 4.7 & 0.16 & 4.10 & 1.73 & 0.42 & 0.26 & 2.42 & 6.52 & 36.6 & 11.94 & 1.74 & 10.16 \\
\hline Test F & n.s. & n.s. & n.s. & n.s. & n.s. & n.s. & n.s. & n.s. & n.s. & n.s. & n.s. & n.s. & n.s. \\
\hline C.V. & 33.0 & 6.4 & 84.4 & 14.3 & 31.2 & 34.0 & 35.7 & 28.62 & 9.3 & 23.5 & 24.28 & 21.89 & 24.28 \\
\hline \multicolumn{14}{|c|}{$0.05-0.10 \mathrm{~m}$} \\
\hline Average & 37.4 & 4.4 & 0.35 & 4.35 & 1.30 & 0.26 & 0.15 & 1.71 & 6.06 & 28.1 & 8.59 & 0.70 & 7.89 \\
\hline Test F & n.s. & n.s. & n.s. & n.s. & n.s. & n.s. & n.s. & n.s. & n.s. & n.s. & n.s. & n.s. & n.s. \\
\hline C.V. & 37.3 & 6.5 & 62.8 & 9.6 & 33.62 & 38.8 & 34.0 & 31.1 & 7.8 & 24.7 & 14.89 & 22.04 & 17.78 \\
\hline \multicolumn{14}{|c|}{$0.10-0.20 \mathrm{~m}$} \\
\hline Average & 25.6 & 4.3 & 0.53 & 4.37 & 1.01 & 0.23 & 0.12 & 1.36 & 5.73 & 23.7 & 13.74 & 1.16 & 12.58 \\
\hline Test F & n.s. & n.s. & n.s. & n.s. & n.s. & n.s. & n.s. & n.s. & n.s. & n.s. & n.s. & n.s. & n.s. \\
\hline C.V. & 52.3 & 5.4 & 44.3 & 10.3 & 43.1 & 40.1 & 28.0 & 39.5 & 8.8 & 33.0 & 11.92 & 22.69 & 12.82 \\
\hline
\end{tabular}

n.s. = not significative. $\mathrm{C} . \mathrm{V} .=$ coeficient of variation.

None of the treatments influenced the carbon stock in the soil (TOC, LOC, and MOC) for all evaluated depth layers (Table 4). MOC averages were higher than LOC ones in all layers, with higher LOC concentration at $0.00-0.05 \mathrm{~m}$ depth. Such a pattern was already expected because topsoil is mostly influenced by plant material accumulated on the surface (Tivet et al., 2013).

TOC averages in the $0.00-0.05,0.05-0.10$, and $0.10-20 \mathrm{~m}$ depth layers were $11.94,8.59$, and 13.74 Mg ha-1, respectively. These contents are considered low when compared to those of native forests and pastures, but regular in agricultural lands with soils derived from the Caiuá Sandstone, given their low clay contents (Fidalski, Tormena, Alves and Auler, 2013; Viana, Batista, Tormena, Costa, \& Inoue, 2011). Troeh and Thompson (2007) reported that organic matter decomposes faster in sandy soils than in clayey soils, which hinders its accumulation. This may explain the lack of effect of the treatments on soil chemical properties (Table 4), which vary with TOC in soils from the Caiuá Sandstone (Fidalski et al., 2010). 
The fact that organic carbon stocks and soil nutrients did not differ (Table 4) suggests that the highest soybean yield in treatment 5 was related to previous crops, in this case, buckwheat followed by white oats. These crops must have had a positive influence on soil water maintenance during drought months.

\section{Conclusions}

Soybeans have increased grain yields when sown after white oat crops.

Crop rotation system with lupine/corn + brachiaria, beans/corn, buckwheat/white oats/ soybeans increases plant dry matter yields.

Soil chemical properties were not affected by the studied cropping systems until the third year of cultivation.

\section{Acknowledgments}

The authors would like to thank the administrator of the Umuarama Experimentation Area, $\mathrm{Mr}$ Dieisson Luiz Gonçalves, for his dedication and effort to this experiment.

\section{References}

Alvarenga, R. C., Cabezas, W. A. L., Cruz, J. C., \& Santana, D. P. (2001). Plantas de cobertura de solo para sistema plantio direto. Informe Agropecuário, 22(208), 25-36. Recuperado de file://C:/Users/ eiapar-32051/Downloads/Plantas-cobertura.pdf

Barbosa, M. C., Braccini, A. L., Scapim, C. A., Albrecht, L. P., Piccinin, G. G., \& Zucareli, C. (2013). Desempenho agronômico e componente da produção de cultivares de soja em duas épocas de semeadura no arenito Caiuá. Semina: Ciências Agrárias, 34(3), 945-960. doi: 10.5433/1679-0359.2013v34n3p945

Cambardella, C. A., \& Elliott, E. T. (1992). Particulate soil organic-matter changes across a grassland cultivation sequence. Soil Science Society of America Journal, 56(2), 777-783. doi: 10.2136/sssaj1992. $03615995005600030017 \mathrm{x}$
Campos, L. P., Leite, L. F. C., Maciel, G. A., Iwata, B. F., \& Nóbrega, J. C. A. (2011). Atributos químicos de um Latossolo Amarelo sob diferentes sistemas de manejo. Pesquisa Agropecuária Brasileira, 46(12), 1681-1689. doi: 10.1590/S0100204X2011001200014

Carvalho, M. A. C., Athayde, M. L. F., Soratto, R. P., Alves, M. C., \& Arf, O. (2004). Soja em sucessão a adubos verdes no sistema de plantio direto e convencional em solo de Cerrado. Pesquisa Agropecuária Brasileira, 39(11), 1141-1148. doi: 10.1590/S0100-204X2004001100013

Debiasi, H., Leiven, R., Trein, C. R., Conte, O., \& Kaminura, K. M. (2010). Produtividade de soja e milho após coberturas de inverno e descompactação mecânica do solo. Pesquisa Agropecuária Brasileira, 45(6), 603-612. doi: 10.1590/S0100204X2010000600010

Empresa Brasileira de Pesquisa Agropecuária (2017). Manual de métodos de análise de solo. Brasília, DF: EMBRAPA.

Fidalski, J., Auler, P. A. M., Beraldo, J. M. G., Marur, C. J., Faria, R. T., \& Barbosa, G. M. C. (2010). Availability soil water under tillage systems, mulching management and citrus rootstocks. Revista Brasileira de Ciência do Solo, 34(3), 917-924. doi: 10.1590/S0100-06832010000300033

Fidalski, J., Tormena, C. A., Alves, S. J., \& Auler, P. A. M. (2013). Influência das frações de areia na retenção e disponibilidade de água em solos das formações Caiuá e Paranavaí. Revista Brasileira de Ciência do Solo, 37(3), 613-621. doi: 10.1590/ S0100-06832013000300007

Franchini, J. C., Balbinot, A. A., Jr., Debiasi, H., Costa, J. M., Sichieri, F. R., \& Teixeira, L. C. (2016). Soja em solos arenosos: papel do Sistema Plantio Direto e da Integração Lavoura-Pecuária. (Circular Técnica, 116). Londrina, PR: EMBRAPA.

Franchini, J. C., Costa, J. M., Debiasi, H., \& Torres, E. (2011). Importância da rotação de culturas para a produção agrícola sustentável no Paraná. (Documento, 327). Londrina, PR: EMBRAPA.

Franchini, J. C., Debiasi, H., Sacoman, A., Nepomuceno, A. L., \& Farias, J. R. B. (2009). Manejo do solo para redução das perdas de produtividade pela seca. (Documento, 314). Londrina, PR: EMBRAPA.

Gee, G. W., \& Bauder, J. W. (1986). Particle-size analysis. In A. Klute (Ed.), Methods of soil analysis: physical and mineralogical properties (pp. 383-411). Madison: American Society of Agronomy. 
Instituto Agronômico do Paraná (2020). Médias históricas em estações do IAPAR. Recuperado de http:// www.iapar.br

Linzameyer, R., Jr., Guimarães, V. F., Santos, D., \& Bencke, M. H. (2008). Influência de retardante vegetal e densidades de plantas sobre o crescimento, acamamento e produtividade da soja. Acta Scientiarum Agronomy, 30(3), 373-379. doi: 10.4025/actasciagron.v30i3.3547

Llanillo, R. F., Grossi, M. E., Santos, F. O., Munhos, P. D., \& Guimarães, M. F. (2006). Regionalização da agricultura do Estado do Paraná, Brasil. Ciência Rural, 36(1), 120-127. doi: 10.1590/S0103-84782 006000100018

Marun, F. (1996). Propriedades físicas e biológicas de um Latossolo Vermelho Escuro do arenito Caiuá sob pastagem e culturas anuais. Pesquisa Agropecuária Brasileira, 31(8), 593-597. Recuperado de https:// seer.sct.embrapa.br/index.php/pab/article/ view/4522/1808

Ministério da Agricultura, Pecuária e Abastecimento (2017). Projeções do agronegócio 2016/2017 a 2026/2027. Brasília. Recuperado de http://www. agricultura.gov.br/assuntos/politica-agricola/ todas-publicacoes-de-politicaagricola/projecoesdo-agronegocio/projecoes-do-agronegocio-2017-a2027-versaopreliminar-25-07-17.pdf

Pavan, M. A., Bloch, M. F., Zempulski, H. C., \& Miyazawa, M. (1992). Manual de análise química de solo e controle de qualidade. (Circular Técnica, 76). Londrina, PR: IAPAR.

Perini, L. J., Fonseca, N. S. Jr, Destro, D., \& Prete, C. E. C. (2012). Componentes da produção em cultivares de soja com crescimento determinado e indeterminado. Semina: Ciências Agrárias, 33(1), 2531-2544. doi: 10.5433/1679-0359.2012v33Supl1p2531

Rosset, J. S., Lana, M. C., Pereira, M. G., Schiavo, J. A., Rampim, L., \& Sarto, M. V. M. (2016). Frações químicas e oxidáveis da matéria orgânica do solo sob diferentes sistemas de manejo, em Latossolo Vermelho. Pesquisa Agropecuária Brasileira, 51(9), 1529-1538. doi: 10.1590/s0100-204x 20160009 00052

Sá, J. C. M., Santos, J. B., Canalli, L. B. S., Inagaki, T. M., Gonçalves, D. R. P., Romaniw, J., Ferreira A. O., Briedes, C. (2019). Sistema plantio direto. In O. J. Bertol, A. Colozzi, G. M. C. Fo, Barbosa, J. B. Santos, \& M. F. Guimarães (Eds.), Manual de manejo e conservação do solo e da água para o Estado do Paraná (pp. 105-111). Curitiba, PR: SBCS/NEPAR.
Sá, J. C. M., Séguy, L., Tivet, F., Lal, R., Bouzinac, S., Borszowskei, P. R.,... Friedrich, T (2015). Carbon depletion by plowing and its restoration by notill cropping systems in Oxisols of subtropical and tropical agro-ecoregions in Brazil. Land Degradation \& Development, 26(6), 531-543. doi: 10.1002/ldr. 2218

Sá, J. C. M., Tivet, F., Lal, R., Briedis, C., Hartman, D. C., Santos, J. Z., \& Santos, J. B. (2014). Long-term tillage systems impacts on soil C dynamics, soil resilience and agronomic productivity of a Brazilian Oxisol. Soil \& Tillage Research, 136, 38-50. doi: 10.1016 / j.still.2013.09.010

Santos, H. G., Jacomine, P. K. T., Anjos, L. H. C., Oliveira, V. A., Lumbreras, J. F., Coelho, M. R.,... Cunha, T. J. F. (2018). Sistema brasileiro de classificação de solos. Brasília, DF: EMBRAPA.

Santos, H. P., Fontaneli, R. S., Spera, S. T., \& Tomm, G. O. (2009). Efeito de sistemas de produção integração lavoura-pecuária (ILP) sobre a fertilidade do solo em plantio direto. Acta Scientiarum. Agronomy, 31(4), 719-727. doi: 10.4025/actasciagron.v31i4.925

Santos, J. B. (2010). Carbono e nitrogênio em classes de solos com diferentes texturas e tempo de adoção do sistema plantio direto - espacialização e contribuição do sistema. Tese de doutorado, Universidade Federal do Paraná, Curitiba, PR, Brasil.

Secretaria da Agricultura e do Abastecimento Departamento de Economia Rural (2020). Estimativa de safra. Recuperado de http://www.agricultura. pr.gov.br

Silva, M., Souza, H. R. T., David, H. M. S. S., Santos, L. M., Silva, R. F., \& Amaro, H. T. R. (2014). Qualidade fisiológica e armazenamento de sementes de feijãocomum produzidas no norte de Minas Gerais. RevistaAgro@mbiente On-line,8(1),97-103. doi: 10.18227/1982-8470ragro.v8i1.1346

Statistical Analysis System Institute (2009). SAS/STAT: user's Guide. Version 9.2. Cary, NC: SAS Institute.

Tivet, F., Sá, J. C. M., Lal, R., Briedis, C., Borszowskei, P. R., Burkner, J. D. S.,... Bouzinac, S. L. S. (2013). Aggregate $\mathrm{C}$ depletion by plowing and its restoration by diverse biomass- $C$ inputs under notill in subtropical and tropical regions of Brazil. Soil \& Tillage Research, 126, 203-218. doi: 10.1016/j.still.2012. 09.004

Troeh, F. R., \& Thompson, L. M. (2007). Solos e fertilidade do solo. São Paulo, SP: Andrei Editora. 
Viana, T. E., Batista, M. A., Tormena, C. A., Costa, S. A. C., \& Inoue, T. T. (2011). Atributos físicos e carbono orgânico em Latossolo Vermelho sob diferentes sistemas de uso e manejo. Revista Brasileira de Ciência do Solo, 35(6), 2105-2114. doi: 10.1590 / s0100-06832011000600025
Wendler, E., \& Simonetti, A. P. M. M. (2016). Uso de trigo mourisco sobre a germinação e desenvolvimento inicial de soja. Cultivando o Saber, 9(edição especial), 122-131. Recuperado de https://www.fag.edu.br/ upload/revista/cultivando_o_saber/59300c9a54e80. pdf 